\title{
Effects of burning on soil macrofauna in a savanna-woodland under different experimental fuel load treatments
}

Article in Applied Soil Ecology · April 2014

Impact Factor: $2.64 \cdot$ DOI: 10.1016/j.apsoil.2014.04.005

CITATION

1

3 authors, including:
READS

\section{Patrice Savadogo}

Consultative Group on International Agricu... 52 PUBLICATIONS 622 CITATIONS SEE PROFILE
Hassan Bismarck Nacro

Université polytechnique de Bobo-Dioulasso 39 PUBLICATIONS 148 CITATIONS

SEE PROFILE 


\title{
Effects of burning on soil macrofauna in a savanna-woodland under different experimental fuel load treatments
}

\author{
Sabine W.M.F. Doamba ${ }^{\mathrm{a}, *}$, Patrice Savadogo ${ }^{\mathrm{b}, \mathrm{c}}$, Hassan Bismarck Nacro ${ }^{\mathrm{a}}$ \\ a Université Polytechnique de Bobo-Dioulasso, Institut du Développement Rural, Laboratoire d'Etude et de Recherche sur la Fertilité du Sol, \\ 01 BP 1091 Bobo-Dioulasso, Burkina Faso \\ ${ }^{\mathrm{b}}$ Centre National de Recherche Scientifique et Technologique, Institut de l'Environnement et de Recherches Agricoles, Département Productions Forestières, \\ 03 BP 7047 Ouagadougou 03, Burkina Faso \\ ${ }^{\mathrm{c}}$ World Agroforestry Centre (ICRAF)/International Crop Research Institute for the Semi-Arid Tropics (ICRISAT), West and Central Africa Region-Sahel Node, \\ BP 12404 Niamey, Niger
}

\section{A R T I C L E I N F O}

\section{Article history:}

Received 14 June 2013

Received in revised form 9 April 2014

Accepted 10 April 2014

\section{Keywords:}

Disturbance

Fire severity

Soil biodiversity

Invertebrates

Community changes

Burning impacts

\begin{abstract}
A B S T R A C T
In West African savanna-woodland, the use of prescribed burning as a management tool has ecologica implications for the soil biota. Yet, the effects of fire on soil inhabiting organisms are poorly understood. The aim of this study was to examine the responses of soil macro-invertebrates to early fires in a Sudanian savanna-woodland on a set of experimental plots subject to different fuel load treatments. The abundance of major macro-invertebrate taxa and functional groups, and taxon richness were quantified in soil cores collected from three different soil layers before and immediately after burning. The results indicated that, overall, there was substantial spatial and temporal variation in the composition of macroinvertebrate assemblages. The immediate effects of fire were to reduce total invertebrate numbers and numbers of many invertebrate groups dramatically. This is probably due to the fact that many of the surface-dwelling macrofauna perished as a result of less favorable microclimate due to fire, diminished resources, or migrate to safer environments. Fuel load treatment did not affect the community taxonomic richness or abundance of the soil-dwelling fauna. Furthermore, annual changes in community composition were more pronounced at the burnt site than in the control. This could be related to the inter-annual difference in precipitation pattern recorded during the two-year study period at our site. Since soil macrofauna population declines in fire-disturbed areas, increasing fire prevalence may jeopardize the long-term conservation of fire sensitive macrofauna groups. Special fire management attention is therefore recommended with due consideration to the type of burning and fuel properties to avoid the detrimental effects of intense fire affecting the resilience of savanna soil macrofauna species.
\end{abstract}

(C) 2014 Elsevier B.V. All rights reserved.

\section{Introduction}

Fires are considered the most important natural disturbance agent in various ecosystems, including savannas (Goldammer, 1990; Swaine et al., 1992), grasslands (Briggs and Knapp, 1995; Pyne et al., 1996) and forests (Theresa et al., 2008). Frequent fires are a product of the annual cycle of massive wet season vegetative production that provides dry fuel loads, after seasoning, through the ensuing dry season (Cheney and Sullivan, 1997; Dawes-Gromadzki, 2007). Fire produces a wide spectrum of responses in the affected ecosystems depending on the interaction between many factors, including fire severity, fire intensity, duration of temperatures,

\footnotetext{
* Corresponding author. Tel.: +226 70133571; fax: +226 20982577.

E-mail address: doambaflore@yahoo.fr (S.W.M.F. Doamba).
}

fuel loading, degree of combustion, vegetation type, climate, slope, topography, soil characteristics, time since the last fire and area burned (Neary et al., 1999).

Soil is an important component of ecosystems that are likely to be affected by fire (Savadogo et al., 2007; Badía-Villas et al., 2014), and the soil biota is one of the first soil components to respond to fire exposure (Bezkorovainaya et al., 2007; Vasconcelos et al., 2009). Fires affect many of the soil organisms that interact with the below-ground environment either directly or indirectly. Direct effects cause short-term changes, which are reflected in altered species composition and changes in the abundance of some taxonomic groups (Wikars and Schimmel, 2001). Heat penetration into the soil during a fire affects the survival of organisms; either the animals or their eggs are directly killed or injured by the flames or by the heat of the fire or by smoldering material. Indirect effects are usually associated with long-term changes in the environment 
that affect the welfare of organisms located below the soil surface (DeBano et al., 1998). These indirect effects can involve competition for habitat, food supply and other more subtle changes in microclimate (destruction of soil organic matter status, increased surface insolation, temperature or $\mathrm{pH}$ ) that affect the reestablishment and succession of plants and animals (DeBano et al., 1998; Debouzie et al., 2002). There is great variation in the way the soil fauna (in terms of composition and abundance) respond to fire, depending on the intensity, frequency and season of burning, as well as preand post-fire conditions (DeBano et al., 1998). Low-severity, rapidly moving fires do not have a major effect, whereas high-severity fires that last a long time have the greatest impact. Moreover, macrofauna species may react in various ways to fire; for instance while some invertebrates can burrow, migrate downward or fly to escape a fire, species with immobile life stages (larvae, pupae) that occur in the surface litter or on above-ground plant tissue are more vulnerable (Malmström et al., 2009; Gongalskya et al., 2012).

In the Sudanian savanna-woodland, fire is widely used as a conservation management tool (Bellefontaine et al., 2000; Sawadogo et al., 2005). Prescribed early fire (burning taking place between October and December-January when the fuel moisture content is at a minimum of $40 \%$ ) is recommended by managers as the only practical alternative to, often unavoidable, late fires (set from February and just before the next rainy season in May) in the season which are reported to be detrimental to biodiversity and maintenance of the ecosystem's structure and function (Laris and Wardell, 2006). Most studies focusing on how biodiversity is affected by fires have considered plant species which had site specific response to fire (Zida, 2007; Savadogo et al., 2008). Knowledge about the effect of fire on soil biota is limited especially in relation to west Africa (Louppe et al., 1998). In this continent, most research has been conducted in South Africa and has involved studying the impact of repeated fires on fauna (Foord et al., 2003; Uys and Hamer, 2007; Oluwole et al., 2008). Frequent burning may affect soil organic resource quality and quantity thereby leading to increase or decrease in soil macrofaunal population depending on time of burning occurrence and intensity. The results of other previous studies have revealed the adverse effects of increasing fire frequency and intensity on soil fauna communities (Decaëns et al., 1994; CastanoMeneses and Palacios-Vargas, 2003). Some studies have reported that late fire has a much greater destructive impact on soil fauna population density and diversity than early fires (Louppe et al., 1998). In contrast, other studies in South Africa have recorded a significant increase in the soil macrofauna population (Oluwole et al., 2008). An increase of $31.4 \%$ in the population density was noted in an annually burned stand against a reduction of the population in stands burned every six years.

Understanding the effect of fire on macrofauna is of value to both conservationists and ecologists (Uys and Hamer, 2007) because this component of the biota performs critical ecosystem functions in soil nutrient cycles, pest control, pollination and waste disposal. Therefore, this study was designed to fill the knowledge gap by contributing to our understanding of the factors that regulate the structure of soil faunal communities in fire-adapted ecosystems (Frost and Robertson, 1987) like savanna-woodland and elucidating the consequences of this for ecosystem function. Specifically we quantified soil macrofauna taxonomic richness and density under different fuel loads and pre-post fire changes for an informed management that will enhance soil macrofauna resilience to facilitate effective ecosystem functioning. We hypothesize that the survival of soil-living macrofauna depends on both the fuel load quantity and the pre-post fire environment; that in high fuel loaded plots and post fire conditions soil macrofauna do not recover to preburn levels in short term. In addition, we hypothesize that there is vertical stratification of the fire effect, with large proportions of individuals being affected in the top soil layer.

\section{Material and method}

\subsection{Study site description}

The study was conducted in Burkina Faso (West Africa) in the Dindéresso State Forest Reserve $\left(11^{\circ} 13^{\prime} 59.88^{\prime \prime} \mathrm{N}\right.$ and $\left.4^{\circ} 25^{\prime} 59.59^{\prime \prime} \mathrm{W}\right)$. The forest was delimited by the colonial French administration on July 4, 1935 and today covers 8500 ha. The climate at this location is south-Sudanian with two main seasons: the rainy season extends from May to October and the dry season from October to April (Fontès and Guinko, 1995). Rainfall and temperature data were collected at the synoptic station within the airport $\left(11^{\circ} 09^{\prime} 36^{\prime \prime} \mathrm{N}\right.$ and $\left.4^{\circ} 19^{\prime} 51^{\prime \prime} \mathrm{W}\right)$ located about $20 \mathrm{~km}$ from the study site (ASECNA-Agence pour la Sécurité de la Navigation Aérienne en Afrique et à Madagascar). The mean annual rainfall for the study period, 2009-2011, was $1010 \pm 145 \mathrm{~mm}$ (mean \pm standard error). The lowest rainfall $(831 \mathrm{~mm})$ was recorded in 2011 and the highest $(1290 \mathrm{~mm}$ ) in 2010 . Besides the yearly variation, some monthly variations are also observed; most rain falls between June and September with the maximum in August. Mean daily minimum and maximum temperatures ranged from 16 to $32^{\circ} \mathrm{C}$ in January (the coldest month) and from 26 to $40^{\circ} \mathrm{C}$ in April (the hottest month). Soils at the reserve are derived from sedimentary substrates and classified as Lixisols according to Driessen et al. (2001). The soil characterization across the entire reserve indicated that they are mainly deep (>85 cm) and dominated by a sandy loam texture $(57.5 \%)$ followed by sandy textures (17.5\%), loamy sand (15\%) and loamy silty clay textures (10\%). They have poor fertility status (pH 5.95; N: 0.058\%; P: 1.77 ppm; C: 0.33\%) and low organic matter content (OM: 0.57\%) (BUNASOLs, 1985). Phyto-geographically, the study site is located in the Sudanian regional center of endemism in the south Sudanian Zone (Fontès and Guinko, 1995). The Sudanian savanna is an area stretching across the African continent from Senegal in the west to the Ethiopian highlands in the east and is characterized by a dry season lasting 6-7 months and a mean annual rainfall between 700 and $1200 \mathrm{~mm}$ (Menaut et al., 1995). The vegetation type at the site is a tree/bush savanna with a grass layer dominated by the annual grasses Andropogon pseudapricus Stapf. and Loudetia simplex (Pilger) C.E. Hubbard as well as the perennial grasses Andropogon gayanus Kunth. and Andropogon ascinodis C.B.Cl. Species in the families Combretaceae, Mimosaceae and Cesalpiniaceae dominate the woody vegetation component. In terms of cover, the main woody species are Combretum nigricans Lepr. ex Guill. \& Perr., Acacia macrostachya Reichenb. Ex Benth., Anogeissus leiocarpus (DC.) Guill. \& Perr. and Vitellaria paradoxa C.F. Gaertn.

\subsection{Burning experiment and fuel load treatments}

The investigation of soil physical and chemical properties was performed at an experimental site which was established in August 2009. The plots were located on flat ground to eliminate the influence of slope on fire behavior (Trollope et al., 2002). The experimental area (11.16 ha) comprised three non-contiguous blocks (3.72 ha) (Fig. 1). The blocks were located to as to minimize variation in aspect, slope, and soil type after a preliminary reconnaissance survey. Each block was further divided into seven plots of 0.24 ha $(80 \times 30 \mathrm{~m})$. The plots were separated from each other by $10 \mathrm{~m}$ fire-breaks and each block was surrounded by a $20 \mathrm{~m}$ wide fire-break. All the blocks were similar and have been subject to moderate grazing, mainly by livestock (a mixed herd of cattle, sheep and goats) all year round. The woody vegetation covers an average of $44 \%$ in each plot.

The fuel load treatment procedure was as follow: first, except on the control plot, the herbaceous vegetation was harvested manually by cutting at the base, approximately $10 \mathrm{~cm}$ above the ground. 


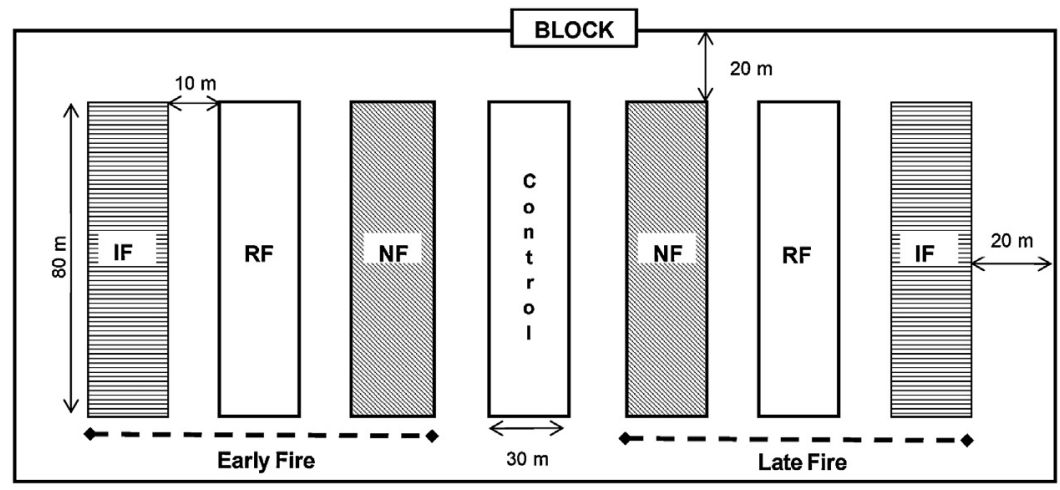

Fig. 1. Experimental set up (NF: normal fuel load; RF: reduced fuel load; IF: increased fuel load. This design was replicated at three different locations).

The harvested biomass and available plant litter were weighed in situ before taking the material to the laboratory, where biomass was determined by again weighing, then it was placed in an oven for $48 \mathrm{~h}$ at $105^{\circ} \mathrm{C}$, and finally reweighed. Fire is applied on the same day when the cutting occurred. Based on the dry weight of the material from each plot, three fuel load treatments were considered prior to early and late burning:

- normal fuel load (NF), the initial available fuel was cut and left having been spread uniformly across the plot to ensure 100\% fuel bed continuity by covering any areas of bare soil;

- reduced fuel load treatment (RF): half of the initial fuel load was left on the plot and the rest removed;

- increased fuel load (IF): the second half of the fuel removed from RF was added to the initial fuel collected on the IF plots, all of it was spread out evenly.

Further, the following fire treatments, each with 3 replicates, were randomly assigned to the 21 plots starting in 2009: no fire: control plots; early fire: fire set at the beginning of the dry season in December; and late fire: fire set at the end of the dry season and just before the next rainy season at the end of February. The fuel load was $1.64 \pm 0.47,1.31 \pm 0.38$ and $0.64 \pm 0.18 \mathrm{~T} \mathrm{ha}^{-1}$ on the IF, NF and RF plots, respectively. In each season, fire was initiated early in the morning ( $6 \mathrm{am}$ to $9 \mathrm{am}$ ) when the wind speed and air temperature were lowest. The fires were lit by ignition with a drip torch all along one side of each plot to establish a fire line rapidly and to ensure linear ignition.

\subsection{Sampling procedure}

Soil macrofauna was sampled at three different points at regular intervals, across the middle of each plot before and after the fire event, in two consecutive years. At the same time, sampling was conducted in control plots protected from fire. At each sample point, one soil block of $25 \mathrm{~cm}$ by $25 \mathrm{~cm}$ to $30 \mathrm{~cm}$ depth was collected and sorted according to the standard method used by the Tropical Soil Biology and Fertility Institute (referred to as the 'TSBF soil monolith method' (Anderson and Ingram, 1993; Moreira et al., 2008)). Litter was collected from within a quadrat of $25 \mathrm{~cm}$ by $25 \mathrm{~cm}$, and a trench excavated to $30 \mathrm{~cm}$ depth around the quadrat. The soil block was removed from the ground, divided into three layers each $10 \mathrm{~cm}$ deep (i.e. $0-10 \mathrm{~cm},<20 \mathrm{~cm}$ and $<30 \mathrm{~cm}$ ), and carefully hand-sorted in a large tray; the macrofauna were collected soil using forceps. Invertebrates were preserved in $70 \%$ alcohol. In total, 63 monoliths were excavated: 54 monoliths from plots subjected to fire ( 27 before and 27 after fire) and 9 monoliths in the control plots. Soil macrofauna, carefully collected, were identified to order using an identification key (Delvare and Aberlenc, 1989) but also with the help of a taxonomist (E. Ilboudo-Tapsoba) from the University of Ouagadougou (Burkina Faso). As juvenile and larval stages of some groups were often difficult to discriminate, identification was done down to the family level as indicated in Mamaev (1972).

\subsection{Data analysis}

Taxonomic richness $(\mathrm{S})$ was estimated as the number of families of macrofauna in the control soil and within each experimental plot and depth of sampling. Specifically, we calculated soil macro-fauna abundance (for $n=3$ replicates). For all parameters, mean values and standard errors are given. The impact of the factors 'treatment', 'depth of soil sampling' and 'environmental conditions' (pre- and post-fire) on the abundance and taxonomic richness of soil fauna groups were tested by means of a generalized linear model (GLM). Typically, the number of individuals (i.e. density) is considered the appropriate measure of species abundance (Magurran, 2004). Taxonomic richness and abundance values therefore exhibited Poisson distributions of errors which were used to provide the best fit for the available datasets (Model 1). As we used count data, a generalized linear model (GLM) with a Poisson distribution was used to take into account of non-normal errors associated with this type of data (Crawley, 2007). When the Poisson GLM exhibited over dispersion (Lindsey, 1999), with a variance larger than the mean, appropriate modeling was based on a quasi-likelihood approach to account for over dispersion by introducing a dispersion parame$\operatorname{ter}(\Phi)$ in the relationship between the variance and mean, where $\sigma^{2}=\Phi \mu$. The dispersion parameter was estimated as the ratio of the deviance to its associated degrees of freedom (McCullagh and Nelder, 1989). For taxonomic richness and abundance the following model was used:

$$
\mathrm{N}_{\text {isk }} \sim \mathrm{P}\left(\exp \left(\mu+\alpha_{s}+\beta_{k}+\gamma_{s k}\right)\right) \text { Model1 }
$$

The magnitude of the effect of treatment, depth and test was determined using the partial eta squared $\left(\eta^{2}\right)$ statistic, and the effect was considered to be small, moderate or large if this statistic had a value of approximately $0.01,0.06$ or 0.14 , respectively (Cohen, 1988). When a significant difference was detected, a pairwise comparison was conducted using Tukey's test at the 5\% level of significance. All statistical analyses were performed with the $\mathrm{R}$ statistical software (R Development Core Team, 2012).

\section{Results}

\subsection{Fuel load parameters and macrofauna abundance and richness}

Overall 444 indiv $\mathrm{m}^{-2}$ were identified before the fire compared to only 87 indiv $\mathrm{m}^{-2}$ after fire during the first year of assessment 
Table 1

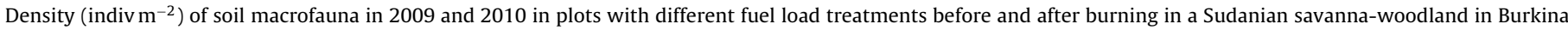
Faso. L: larvae of insects, RF: reduced fuel load; NF: normal fuel load; IF: increased fuel load; CT: control; PRE: pre-fire.

\begin{tabular}{|c|c|c|c|c|c|c|c|c|c|c|}
\hline \multirow[t]{2}{*}{ Classes } & \multirow[t]{2}{*}{ Orders } & \multirow[t]{2}{*}{ Families } & \multicolumn{4}{|l|}{ Year 2009} & \multicolumn{4}{|l|}{ Year 2010} \\
\hline & & & IF & $\mathrm{RF}$ & $\mathrm{NF}$ & $\mathrm{CT}$ & IF & $\mathrm{RF}$ & $\mathrm{NF}$ & $\mathrm{CT}$ \\
\hline Arachnida & Araneae & All Spiders & $3 \pm 2 b$ & $6 \pm 2 b$ & $9 \pm 5 b$ & $4 \pm 2 b$ & 0 & 0 & $2 \pm 1 b$ & $5 \pm b$ \\
\hline Chilopoda & Geophilomorpha & Geophilidae & $2 \pm 1 b$ & $13 \pm 6 b$ & $2 \pm 1 b$ & $2 \pm 1 b$ & $6 \pm 2 b$ & $4 \pm 2 b$ & 0 & $9 \pm 4 b$ \\
\hline Diplopoda & Julida & Julidae & $2 \pm 1 b$ & 0 & $3 \pm 2 b$ & $4 \pm 3 b$ & 0 & $4 \pm 2 b$ & 0 & 0 \\
\hline Diplopoda & Polydesmida & Polydesmidae & 0 & $2 \pm 1 b$ & 0 & 0 & $2 \pm 1 b$ & $9 \pm 2 \mathrm{a}$ & $9 \pm 4 a$ & $15 \pm 11 \mathrm{a}$ \\
\hline Insecta & Hymenoptera & Formicidae & $104 \pm 11 \mathrm{a}$ & $73 \pm 23 a$ & $142 \pm 57 a$ & $98 \pm 29 a$ & $122 \pm 42 \mathrm{a}$ & $22 \pm 9 a$ & $36 \pm 18 a$ & $4 \pm 2 b$ \\
\hline Insecta & Isoptera & Termitidae & $27 \pm 20 \mathrm{a}$ & $244 \pm 60 a$ & $178 \pm 89 a$ & $22 \pm 9 a$ & 0 & 0 & $2 \pm 1 b$ & $4 \pm 2 b$ \\
\hline Insecta & Coleoptera & Scarabaeidae & 0 & $5 \pm 2 b$ & $2 \pm 1 b$ & $9 \pm 2 b$ & 0 & $4 \pm 3 b$ & 0 & 0 \\
\hline Insecta & Coleoptera & Tenebrionidae & 0 & 0 & 0 & $4 \pm 2 b$ & 0 & 0 & 0 & 0 \\
\hline Insecta & Hemiptera & Cydnidae L & $2 \pm 1 b$ & $2 \pm 1 b$ & 0 & 0 & 0 & 0 & 0 & 0 \\
\hline Insecta & Coleoptera & Elateridae L & $3 \pm 2 b$ & $5 \pm 2 b$ & 0 & 0 & 0 & 0 & 0 & 0 \\
\hline Insecta & Coleoptera & Carabidae L & $5 \pm 3 b$ & $3 \pm 1 b$ & 0 & $3 \pm 2 b$ & $3 \pm 2 b$ & $2 \pm 1 b$ & $9 \pm 2 \mathrm{a}$ & $9 \pm 1 b$ \\
\hline Insecta & Coleoptera & Staphylinidae L & $2 \pm 1 b$ & $2 \pm 1 b$ & 0 & 0 & 0 & 0 & 0 & 0 \\
\hline Insecta & Coleoptera & Tenebrionidae L & 0 & $3 \pm 2 b$ & 0 & 0 & $2 \pm 1 b$ & $2 \pm 1 b$ & $6 \pm 2 b$ & 0 \\
\hline Insecta & Coleoptera & Carabidae L & 0 & 0 & 0 & 0 & 0 & 0 & $6 \pm 1 b$ & $3 \pm 2 b$ \\
\hline \multirow[t]{2}{*}{ Oligochaeta } & Haplotaxida & Lumbricidae & 0 & $2 \pm 1 b$ & $2 \pm 1 b$ & 0 & 0 & 0 & 0 & 0 \\
\hline & & Density (indiv $\mathrm{m}^{-2}$ ) & $147 \pm 42 \mathrm{a}$ & $118 \pm 102 a$ & $179 \pm 158 a$ & $78 \pm 51 a$ & $71 \pm 49 a$ & $26 \pm 20 a$ & $33 \pm 29 a$ & $49 \pm 22 \mathrm{a}$ \\
\hline
\end{tabular}

in 2009. These individuals were divided into nine families, belonging to eight orders and four classes (Tables 1 and 2). There was a clear dominance of the class of insects which accounted for $90.7 \%$ of identified individuals; the best represented families were Formicidae (38\% before and $44 \%$ after fire), and Termitidae (53\% before and $49 \%$ after fire). After the fire, the total number of individuals and the mean density (number of indiv $\mathrm{m}^{-2}$ ) decreased sharply in all treatment plots. The reduction in the size of the total community amounted to $85 \%$ on increased fuel load plots (IF), $88.53 \%$ on reduced fuel load plots (RF) and $94.27 \%$ in normal fuel load plots (NF). The overall density of soil fauna ranged from $64 \pm 9$ indiv $\mathrm{m}^{-2}$

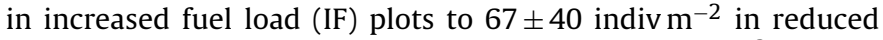
fuel load (RF) plots in 2009 and from $83 \pm 26$ indiv $\mathrm{m}^{-2}$ in IF to $108 \pm 50$ indiv $\mathrm{m}^{-2}$ in RF plots in 2010. In the control plots, soil fauna density was $24 \pm 8$ and $35 \pm 13$ indiv $\mathrm{m}^{-2}$, respectively, in 2009 and 2010. However in the burnt plots there was no significant difference between the fuel load treatments in either 2009 or 2010 (Fig. 2, $p=0.552$ and $p=0.507$, respectively in 2009 and 2010). Further, there was a significant difference between the soil macrofauna groups in all treatment plots (Table 2, $p<0.05$ ). Formicidae and Termitidae families were significantly represented with high abundance in nearly all fuel load treatments plots (Tables 1 and 2). Soil macrofauna taxonomic richness was not affected by fuel load treatment during any of the sampling periods (Fig. 2, $p>0.05$ ). In addition, there were no significant interactions between the main factors (i.e. depth, pre and post fire sampling, and fuel load treatment) in terms of soil macrofauna abundance and richness.

\subsection{Fuel load and macrofauna recovery}

The population dynamics of soil fauna subjected to two consecutive years of burning was marked by an annual variation. Thus, in the second year of burning (2010), there was an increase in the number of individuals and density (number of indiv $\mathrm{m}^{-2}$ ) after burning compared to the situation before burning in most treatment plots; the exception was the increased fuel load plots, where the opposite trend was observed. In contrast, fire induced a significant decrease $\left(F_{[1,36]}=8.587, p=0.005\right)$ in the density of soil fauna during the first year of measurement. It decreased by $90 \%$ in the post fire sample; the soil fauna density was $94 \pm 28$ indiv m $^{-2}$ before the fire and the corresponding value after the fire was $9 \pm 3$ indiv $\mathrm{m}^{-2}$. Moreover, burning resulted in a significant decrease in the density of Formicidae ( $35 \pm 9$ and $4 \pm 2$ indiv $\mathrm{m}^{-2}$, respectively, for pre and post fire sampling) and the effect was large (Table 3 , $\left.F_{[1,36]}=11.561, p<0.001, \eta^{2}=0.182\right)$. Nevertheless, among the soil organisms, the Formicidae and Termitidae were strongly represented in the post-fire sample $\left(F_{[1,90]}=2.527, p=0.004, \eta^{2}=0.204\right.$ in 2009 and $F_{[1,90]}=2.665, p=0.003, \eta^{2}=0.209$ in 2010). The larvae were completely absent from the post fire soil sample in 2009 while in 2010 there was, surprisingly, a larger community after burning

Table 2

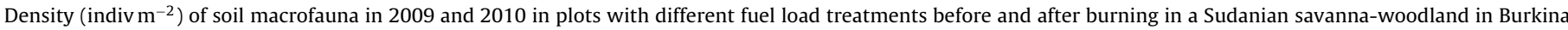
Faso. L-larvae of insects, RF: reduced fuel load; NF: normal fuel load; IF: increased fuel load; CT: control; POS: post-fire.

\begin{tabular}{|c|c|c|c|c|c|c|c|c|}
\hline \multirow[t]{2}{*}{ Classes } & \multirow[t]{2}{*}{ Orders } & \multirow[t]{2}{*}{ Families } & \multicolumn{3}{|c|}{ Year 2009} & \multicolumn{3}{|l|}{ Year 2010} \\
\hline & & & IF & $\mathrm{RF}$ & $\mathrm{NF}$ & IF & $\mathrm{RF}$ & $\mathrm{NF}$ \\
\hline Arachnida & Araneae & All Spiders & 0 & $2 \pm 1 b$ & $2 \pm 1 b$ & $3 \pm 1 b$ & $2 \pm 1 b$ & $2 \pm 1 b$ \\
\hline Chilopoda & Geophilomorpha & Geophilidae & $5 \pm 2 b$ & 0 & 0 & $6 \pm 2 b$ & 0 & $3 \pm 2 b$ \\
\hline Diplopoda & Julida & Julidae & 0 & 0 & 0 & $3 \pm 2 b$ & $4 \pm 2 b$ & $9 \pm 2 b$ \\
\hline Diplopoda & Polydesmida & Polydesmidae & 0 & 0 & 0 & $9 \pm 5 b$ & $13 \pm 6 b$ & $13 \pm 11 b$ \\
\hline Insecta & Hymenoptera & Formicidae & $19 \pm 10 a$ & $2 \pm 1 \mathrm{a}$ & $15 \pm 6 a$ & $53 \pm 25 a$ & $33 \pm 3 a$ & $602 \pm 520 a$ \\
\hline Insecta & Isoptera & Termitidae & 0 & $40 \pm 24 a$ & $3 \pm 2 \mathrm{a}$ & $82 \pm 49 a$ & $524 \pm 255 a$ & $133 \pm 102 a$ \\
\hline Insecta & Coleoptera & Scarabaeidae & 0 & 0 & 0 & 0 & 0 & 0 \\
\hline Insecta & Coleoptera & Tenebrionidae & 0 & 0 & 0 & 0 & 0 & 0 \\
\hline Insecta & Coleoptera & Carabidae L & 0 & 0 & 0 & $2 \pm 1 b$ & 0 & 0 \\
\hline Insecta & Coleoptera & Carabidae L & 0 & 0 & 0 & $9 \pm 5 b$ & 0 & 0 \\
\hline Insecta & Coleoptera & Tenebrionidae L & 0 & 0 & 0 & $6 \pm 1 b$ & $2 \pm 1 b$ & 0 \\
\hline Insecta & Coleoptera & Elateridae L & 0 & 0 & 0 & 0 & $2 \pm 1 b$ & 0 \\
\hline Insecta & Coleoptera & Staphylinidae L & 0 & 0 & 0 & 0 & 0 & $3 \pm 2 b$ \\
\hline Insecta & Hemiptera & Cydnidae L & 0 & 0 & 0 & 0 & $2 \pm 1 b$ & 0 \\
\hline \multirow[t]{2}{*}{ Oligochaeta } & Haplotaxida & Lumbricidae & 0 & 0 & 0 & $2 \pm 1 b$ & 0 & 0 \\
\hline & & Density (indiv $\mathrm{m}^{-2}$ ) & $24 \pm 12 \mathrm{a}$ & $44 \pm 28 \mathrm{a}$ & $19 \pm 10 \mathrm{a}$ & $173 \pm 94 a$ & $581 \pm 271 a$ & $763 \pm 642 a$ \\
\hline
\end{tabular}



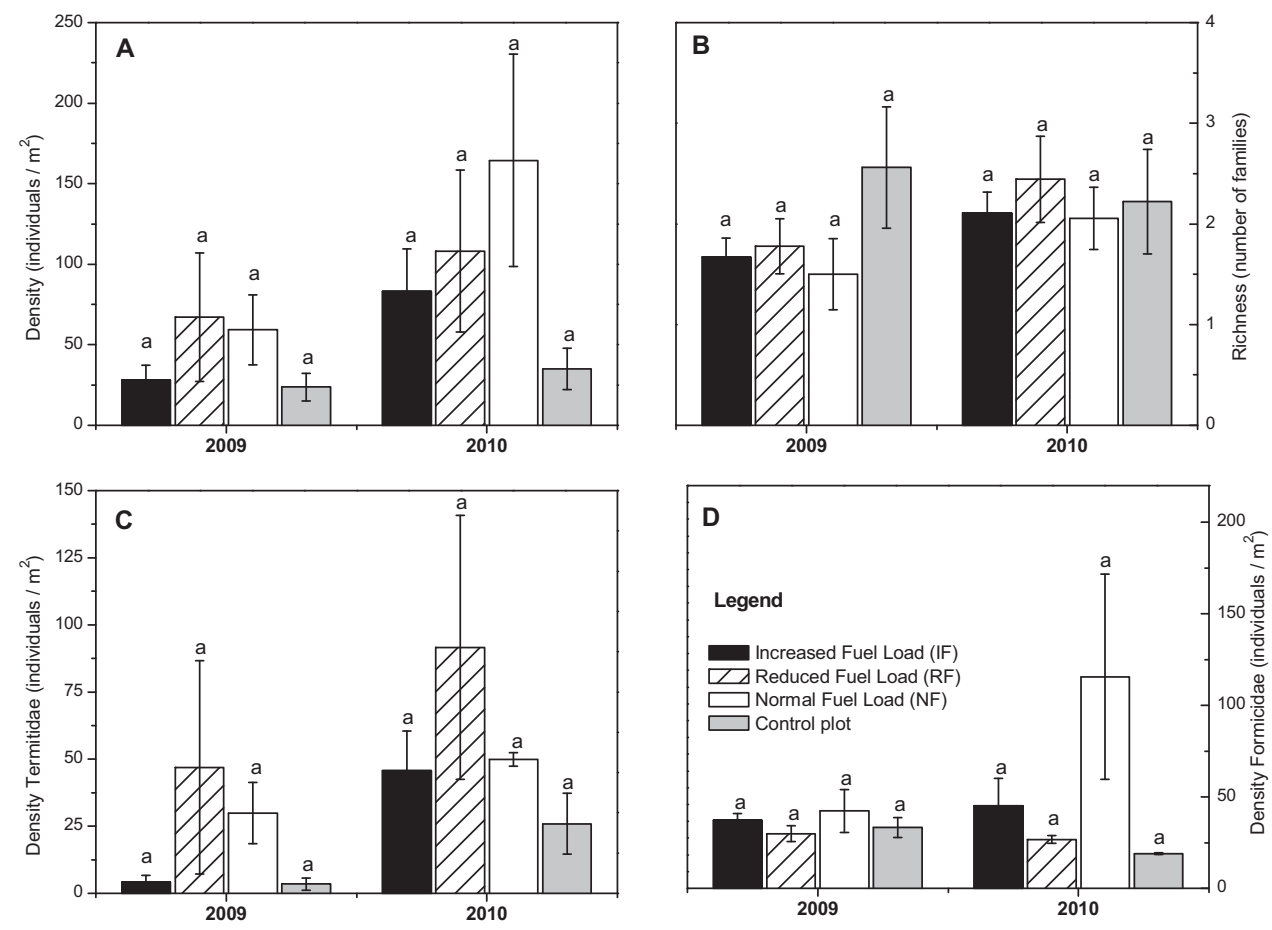

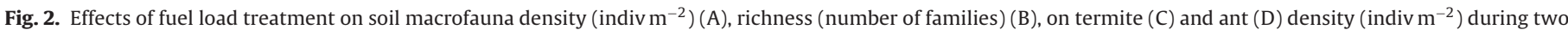

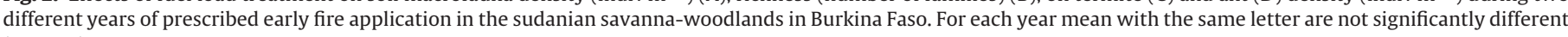
$(p<0.05)$.

Table 3

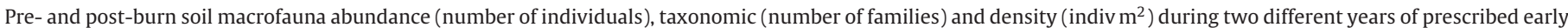

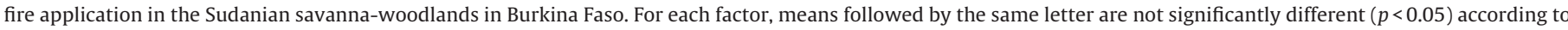
Tukey's HSD.

\begin{tabular}{|c|c|c|c|c|}
\hline \multirow[t]{2}{*}{ Density/diversity parameters } & \multicolumn{2}{|l|}{2009} & \multicolumn{2}{|l|}{2010} \\
\hline & PRE & POST & PRE & POST \\
\hline Overall abundance $(\mathrm{N})$ & $93.50 \pm 28.60 a$ & $9.40 \pm 2.70 b$ & $68.31 \pm 24.90 a$ & $168.888 \pm 50.964 b$ \\
\hline Density formicidae & $35.40 \pm 9.10 a$ & $4.12 \pm 1.61 b$ & $19.92 \pm 11.01 \mathrm{a}$ & $76.38 \pm 41.21 \mathrm{a}$ \\
\hline Density termitidae & $27 \pm 13.80 a$ & $4.61 \pm 2.40 \mathrm{a}$ & $42.14 \pm 18.850 a$ & $82.14 \pm 33.65 a$ \\
\hline Taxonomic richness (S) & $2.60 \pm 0.23 a$ & $0.70 \pm 0.15 b$ & $1.630 \pm 0.28 a$ & $2.78 \pm 0.26 b$ \\
\hline
\end{tabular}

than before. The fire event induced a significant change in the taxonomic richness of the soil macrofauna. During the first year of sampling (Table 3, $F_{[1,36]}=46.446, p=0.000, \eta^{2}=0.563$ ), the highest taxonomic richness was found in the pre-burn soil, while during the second sampling the highest value was found in post-burn sample (Table 3).

\subsection{Variation of macrofauna between top soil layers}

The soil fauna density was not affected significantly in the different topsoils during the two years of investigation (Fig. 3, $p>0.05$ ). Considerable within-plot variability was observed for the main taxa (Termitidae, Formicidae, Geophilidae, Julidae) although this was not always significant. The main effect of depth of soil sampling was not significant for the Formicidae (Fig. $3, F_{[1,36]}=1.268, p=0.290$, $\eta^{2}=0.047$ ), but some variations exist between different soil profiles. Their density was higher $\left(30 \pm 13\right.$ indiv $\left.\mathrm{m}^{-2}\right)$ in the $10-20 \mathrm{~cm}$ layer than the $0-10 \mathrm{~cm}$ layer $\left(10 \pm 4\right.$ indiv m$\left.^{-2}\right)$ and the $20-30 \mathrm{~cm}$ layer $\left(19 \pm 7\right.$ indiv $\left.\mathrm{m}^{-2}\right)$; the latter two were similar. In addition, the main factors (i.e. depth, pre and post fire sampling, fuel load treatment) had no significant effect on the density of Termitidae $(p>0.05)$ in the second year of investigation and there were no significant interactions. Furthermore, there was no effect of fire treatments on the depth distribution of soil macrofauna taxonomic richness during the first sampling year. However, during the second year, these fire treatments significantly affected the depth distribution of soil macrofauna taxonomic richness and the difference was large (Fig. 3B, $F_{[1,36]}=3.391, p=0.045, \eta^{2}=0.159$ ). The effect was similar in the top two horizons, but somewhat different in the lower horizon (Fig. 3B).

\section{Discussion}

\subsection{Fuel load parameters and macrofauna abundance and richness}

Overall, there was substantial spatial and temporal variation in the composition of macro-invertebrate assemblages. As expected, invertebrates collected at recently burnt sites (post-fire in 2009) showed that the immediate effects of fire were to reduce dramatically total invertebrate numbers and numbers of many component invertebrate groups. This is probably due to the fact that many of the surface-living macrofauna either die in the fire or migrate to safer environments. This observation is in agreement with previous studies (Louppe et al., 1998; Malmström et al., 2009). At Lamto in Côte d'Ivoire (West Africa), a study of the effect of fire on soil macrofauna indicated a decrease of $39.95 \%$ and $59.60 \%$, respectively, during early and late fires (Louppe et al., 1998). Fire destroys 

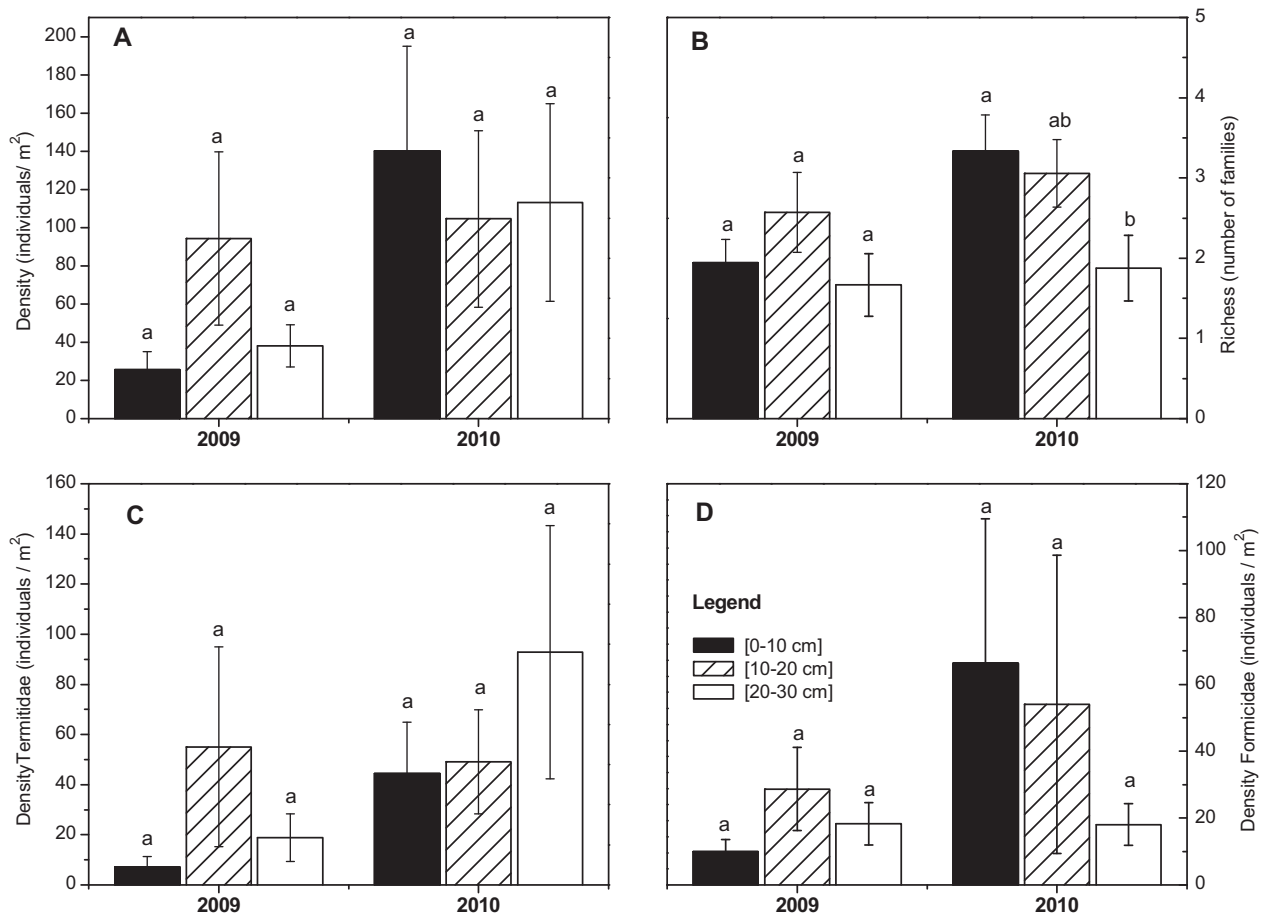

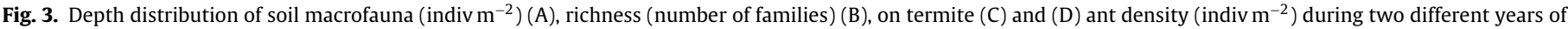
prescribed early fire application in the Sudanian savanna-woodlands in Burkina Faso. For each year mean with the same letter are not significantly different $(p<0.05)$.

the preferred part of the soil habitat for most soil organisms, i.e. the litter and uppermost humus layer, or if the fire is very severe, the entire humus layer. This habitat destruction is likely to be the most important factor affecting survival in the soil both during and after a fire. The effect of fire was strongest on species and groups living near the surface, indicating that different species react differently to fire and its intensity. Higher mortality rates (up to $100 \%$ in surface horizons) have been recorded (Wikars and Schimmel, 2001). Mortality of soil macrofauna may be directly caused by flames or smoldering material; also some soil organisms may be susceptible to gas or heat transferred into the soil (Satyam and Jayakumar, 2012).

The results of the study also show that soil organisms are sensitive to fire intensity. Their density decreased by almost half with increasing fuel (IF) during the two years although no significant difference was observed between the fuel load treatments (NF, IF, $\mathrm{RF}$ ). Nevertheless, Formicidae and Termitidae families were significant represented in most fuel load treatments plots. Many authors have reported the harmful effect of fire on soil organisms (DeBano et al., 1998; Gongalskya et al., 2012). These authors indicate that organisms may be trapped in the soil and the heat transferred to the surrounding environment. A more intense fire will release more heat into the soil (Steward et al., 1990) and, thus, kill more animals. This increase may be sufficient to kill or injure many organisms (Satyam and Jayakumar, 2012). Ahlgren (1974) pointed out that faunal responses to fire are associated with variations that depend heavily on the intensity, frequency and fire season. In addition to fire frequency, fire intensity - which may vary temporally and spatially - has been reported to induce depletion in soil macrofauna diversity because it results in the death of organisms (CastanoMeneses and Palacios-Vargas, 2003) or significant depletion in the nutrient capital of the soil. In general, the results revealed also that soil macrofauna taxonomic richness is not affected either by the fuel load treatment or by the sampling periods. This is probably related to the lack of significant difference between the treatments with respect to the fire intensity (Doamba et al., 2014).

\subsection{Fuel load and macrofauna recovery}

Annual variations were observed in the structure, composition and taxonomic richness of soil macrofauna. Thus, contrary to the decrease in density recorded in 2009, an increased number of individuals and density were observed in the second year of burning. This could be related to the inter-annual difference in precipitation pattern during the two-year study period at our site. Experiments conducted in South Africa on the effects of fires on soil macrofauna have also found an increased range from $31.13 \%$ to $51.36 \%$, respectively, associated with repeated annual burning or fire occurring every three years (Oluwole et al., 2008). This variation could be attributed to the fact that the soil did not reach temperatures high enough to kill the invertebrates; but it could also be due to food resource limitation following the release, by burning, into the soil of plant nutrients bound to vegetation and organic dead material. A slight increase in temperature and availability of food (remnants of burned plants and their roots) have been reported to stimulate the proliferation of organisms and the functioning of some groups of soil animals that survive the flames (Blair, 1997). In addition, an analogous variability of taxonomic richness responses of macro-invertebrates has been reported in previous studies (Dawes-Gromadzki, 2007). The fact that taxonomic richness varied between years at burnt sites can be explained by either a change in taxonomic richness or a shift in dominance structure between species.

Our results show that Formicidae and Termitidae groups, survived better than other animals. Furthermore, in South Africa, Parr et al. (2004) showed most Formicidae were present shortly after fires, which is similar to the situation in Australian savanna (Barrow et al., 2007; Parr and Andersen, 2008). In fact, this tolerance can be explained by their preferential establishment of nests in sparsely covered and bare ground and their capacity to live in deep burrows (Lepage, 1974; Underwood and Christian, 2009). Their nests often act as a refuge for them during fires (Decaëns et al., 1994; Gongalskya et al., 2012). The present study also revealed that 
larvae were wiped out by the first fire event in 2009. This is probably because the fire temperature reached or surpassed the threshold lethal temperature for small organisms, i.e. $50^{\circ} \mathrm{C}$ (Lyon et al., 1978; Malmström, 2008). Therefore, organisms were directly killed and their eggs destroyed by the flames or the heat released during combustion.

\subsection{Variation of macrofauna between top soil layers}

Despite of the variability in the different topsoil layers during the two years of investigation, no difference was observed in macrofauna density. However, the depth of soil sampling significantly affected soil macrofauna taxonomic richness with a decreasing trend. Gongalskya et al. (2012) noted that the survival of soildwelling organisms at depth was high compared to those living on the surface or near the surface because of the high risk of being exposed to heat damage. Further, DeBano et al. (1998) suggested that the effects of fire are more pronounced on organisms living in the surface litter. In contrast, those already living deeper in the soil and that are able to migrate downward during the fire can escape damage (McCullough et al., 1998; Wikars and Schimmel, 2001). However, invertebrates response to fire vary among different taxonomic group (Vasconcelos et al., 2009; Andersen et al., 2012). An abundance has often been found to increase on the ground after fire (Andersen, 1988; Pryke and Samways, 2012a,b). The increase in the quantity of available litter materials from dead root mass which is a source of food for the macrofauna immediately after burning could attract some groups to burned areas (Blair, 1997). Reports from other studies showed also that some invertebrate predators are potential contributors to the overall species richness (Pryke and Samways, 2012a,b). These kinds of invertebrate are specially attracted by weakened or injured animals that become easy prey.

\section{Conclusions and management implications}

Fire, as a natural or anthropogenic disturbance, can profoundly influence terrestrial ecosystem structure and function. The aim of this study was to evaluate the immediate effects of prescribed burning on soil-dwelling invertebrates. The results of this study showed that all soil fauna species responded with decreased abundances shortly after burning. This decline can be partly explained by the high temperatures, because most macrofauna cannot survive the lethal temperatures easily exceeded during a fire. Since fire is unavoidable in the savanna ecosystem, its integration in the management plans is required: early fire seems to be a good management option in soil perspective to compromise between total fire protection (which is utopian). Thus, the application of annual early fire could continue with due caution to the timing of burning, weather conditions and other possible factors related to fuel properties that influence fire intensity.

\section{Acknowledgments}

Financial support for this work was provided by the International Foundation for Science (IFS-Stockholm, Sweden), grant agreement no. C/4816-1. We also thank RIPIECSA-project for financial support during the setup of the experiment. Special thanks to our field assistants Boukary Sanou and Elisée Ouattara who provided valuable help during the data collection. The authors thank Edith Ilboudo-Tapsoba from Laboratory of Applied and Fundamental Entomology/University of Ouagadougou for her help in identifying the invertebrates. We are also grateful to Sees-editing Ltd for linguistic improvements and to anonymous reviewers for providing valuable comments.

\section{References}

Ahlgren, I.F., 1974. The effect of fire on soil organisms. In: Kozlowski, T.T., Ahlgren, C.E. (Eds.), Fire and Ecosystem. Academic Press, New York, NY, pp. 47-72.

Andersen, A.N., 1988. Immediate and longer-term effects of fire on seed predation by ants in sclerophyllous vegetation in south-eastern Australia. Aust. J. Ecol. 13, 285-293.

Andersen, A.N., Woinarski, J.C.Z., Parr, C.L., 2012. Savanna burning for biodiversity: fire management for faunal conservation in Australian tropical savannas. Aust. Ecol. 37, 658-667.

Anderson, J., Ingram, J., 1993. Tropical Soil Biology and Fertility: A Handbook of Methods. CAB International, Wallingford, UK.

Badía-Villas, D., José, A., González-Pérez, J.A., Aznar, J.M., Arjona-Gracia, B., MartíDalmau, C., 2014. Changes in water repellency, aggregation and organic matter of a mollic horizon burned in laboratory: soil depth affected by fire. Geoderma 213, 400-407

Barrow, L., Parr, C.L., Kohen, J.L., 2007. Habitat type influences fire resilience of ant assemblages in the semi-arid tropics of northern Australia. J. Arid. Environ. 69, 80-95.

Bellefontaine, R., Gaston, A., Petrucci, Y., 2000. Management of Natural Forests of Dry Tropical Zones. (Conservation Guide 32). Food and Agriculture Organization of the United Nations (FAO), Rome, Italy, pp. 318.

Bezkorovainaya, I.N., Krasnoshchekova, E.N., Ivanova, G.A., 2007. Transformation of soil invertebrate complex after surface fires of different intensity. Biol. Bull. 34 (5), 517-522.

Blair, J.M., 1997. Fire, $\mathrm{N}$ availability and plant response in grasslands: a test of the transient maxima hypothesis. Ecology 78, 2359-2368.

Briggs, J.M., Knapp, A.K., 1995. Interannual variability in primary production in tallgrass prairie-climate, soil-moisture, topographic position, and fire as determinants of aboveground biomass. Am. J. Bot. 82, 1024-1030.

BUNASOLS, 1985. Etat de connaissance de la fertilité des sols du Burkina Faso. In: Documentation Technique No. 1. Ministère Agriculture et Elevage, Bureau National des Sols, Ouagadougou, Burkina Faso.

Castano-Meneses, G., Palacios-Vargas, I.G., 2003. Effects of fire and agricultural practices on neotropical ant communities. Biodivers. Conserv. 12, 1913-1919.

Cheney, N.P., Sullivan, A., 1997. Grassfires: Fuel, Weather and Fire Behaviour. CSIRO Publishing, Melbourne.

Cohen, J., 1988. Statistical Power Analysis for the Behavioral Sciences. Lawrence Erlbaum, Hillsdale, NJ.

Crawley, M.J., 2007. The R Book. John Wiley \& Sons, England.

DeBano, L.F., Neary, D.G., Ffolliott, P.F., 1998. Fire's Effects on Ecosystems. John Wiley\& Sons Inc., New York. NY, pp. 333.

Debouzie, D., Desouhant, E., Oberli, F., Menu, F., 2002. Resource limitation in natural populations of phytophagus insects. A long-term study case with the chestnut weevil. Acta Oecol. 23, 31-39.

Decaëns, T., Lavelle, P., Jiménez-Jaen, J.J., Escobar, G., Rippstein, G., 1994. Impact of land management on soil mcrofauna in the Oriental Lianos of Colombia. Eur. J. Soil Biol. 30, 157-168.

Delvare, G., Aberlenc, H.-P., 1989. Les Insectes d'Afrique et d'Amérique tropicale. In: Clés pour la reconnaissance des familles. PRIFAS, CIRAD-GERDAT, Montpellier, France, pp. 302

Doamba, S.W.M.F., Savadogo, P., Nacro, H.B., 2014. Rôle des feux de savane sur les caractéristiques biogéochimiques des sols en zone soudanienne du Burkina Faso. Int. J. Biol. Chem. Sci. 8 (2), 777-793.

Driessen, P., Deckers, J., Spaargaren, O., 2001. Lecture notes on the major soils of the world. In: FAO World Soil Resources Reports-94. Food and Agriculture Organization of the United Nations, Rome.

Fontès, J., Guinko, S., 1995. Carte de la végétation et de l'occupation du sol du Burkina Faso. In: Notice Explicative CNRS. Université de Toulouse III (France)/Institut du Développement Rural, Faculté des Sciences et Techniques, Université de Ouagadougou, Ouagadougou.

Foord, S.H., Ferguson, J.W.H., van Jaarsveld, A.S., 2003. Coleopteran assemblages in afromontane grassland reflect finescale variation in vegetation. Environ. Entomol. 32, 797-806.

Frost, P.G.H., Robertson, F., 1987. In: Walker, B.H. (Ed.), The Ecological Effects of Fire in savannas, Determinants of Tropical savannas. IRL Press, Oxford, pp. 93-140.

Goldammer, J.G., 1990. Fire in the Tropical Biota: Ecosystem Processes and Global Challenge. Springer-Verlag, Berlin.

Gongalskya, K.B., Malmströmb, A., Zaitseva, A.S., Shakhaba, S.V., Bengtsson, J., Persson, T., 2012. Do burned areas recover from inside? An experiment with soil fauna in a heterogeneous landscape. Appl. Soil. Ecol. 59, 73-86.

Laris, P., Wardell, D.A., 2006. Good, bd or "necessary evil"? Reinterpreting the colonial burning experiments in the savanna landscapes of west Africa. Geog. J. 172, $271-290$.

Lepage, M., 1974. Les termites d'une savane sahélienne (Ferlo Septentrional, Sénégal):peuplement, populations, consommation, rôle dans l'écosystème, Thèse Sicences. Université de Dijon, France, pp. 344.

Lindsey, J.K., 1999. On the use of corrections for overdispersion. J. R. Stat. Soc.: Ser. C 48, 553-561.

Louppe, D., Olivier, R., Ouattara, N., Fortier, M., 1998. Impacts des feux répétés sur les sols des savanes du centre de Côte d'Ivoire. In: Séminaire International sur l'aménagement Intégré des forêts Naturelles des Zones Tropicales Sèches en Afrique de l'Ouest, 16-20 novembre 1998, Ouagadougou, Burkina Faso, p. 11. 
Lyon, L.J., Crawford, H.S., zuhai, E., Fredriksen, R.L., Harlow, R.F., Metz, L.J., Pearson, H.A., 1978. Effects of fire on fauna: a state of knowledge review. In: General Technical Report WO. US Department of Agriculture, Forest Service, pp. 13.

Magurran, A.E., 2004. Measuring Biological Diversity. Blackwell Publishing, Malden, Oxford and Victoria, pp. 256.

Malmström, A., 2008. Temperature tolerance in soil microarthropods: simulation of forest-fire heating in the laboratory. Pedobiologia 51, 419-426.

Malmström, A., Persson, T., Ahlströma, K., Gongalsky, K.B., Bengtsson, J., 2009. Dynamics of soil meso- and macrofauna during a 5-year period after clear-cut burning in a boreal forest. Appl. Soil. Ecol. 43, 61-74.

Mamaev, B.M., 1972. Identification Keys for Insect Larvae. Prosveshenie, Moscow (in Russian).

McCullagh, P., Nelder, J.A., 1989. Generalized Linear Models, second ed. Chapman and Hall, London.

McCullough, D.G., Werner, R.A., Neumann, D., 1998. Fire and insects in northern and boreal forest ecosystems of North America. Annu. Rev. Entomol. 43, 107-127.

Menaut, J.C., Lepage, M., Abbadie, L., 1995. In: Bullock, S.H., Mooney, H.A., Medina, E.E. (Eds.), Savannas, Woodlands and Dry Forests in Africa, Seasonnally Dry Tropical Forests. Cambridge University Press, London, pp. 64-92.

Moreira, F.M.S., Huising, E.J., Bignell, D., 2008. A Handbook of Tropical Soil Biology: Sampling and Characterization of Below-ground Biodiversity. Earthscan, London.

Neary, D.G., Klopatekb, C.C., DeBanoc, L.F., Ffolliottc, P.F., 1999. Fire effects on belowground sustainability: a review and synthesis. For. Ecol. Manage. 122, 51-71.

Oluwole, F.A., Sambo, J.M., Sikhalazo, D., 2008. Long-term effects of different burning frequencies on the dry savannah grassland in South Africa. Afr. J. Agric. Res. 3, 147-153.

Parr, C.L., Andersen, A.N., 2008. Fire resilience of ant assemblages in long-unburnt savanna of northern Australia. Aust. Ecol. 33, 830-838.

Parr, C.L., Robertson, H.G., Biggs, H.C., Chown, S.L., 2004. Response of African savanna ants to long-term fire regimes. J. Appl. Ecol. 41, 630-642.

Pryke, J.S., Samways, M.J., 2012a. Differential resilience of invertebrates to fire. Aust. Ecol. 37, 460-469.

Pryke, J.S., Samways, M.J., 2012b. Importance of using many taxa and having adequate controls for monitoring impacts of fire for arthropod conservation. J. Insect Conserv. 16, 177-185.

Pyne, S.J., Andrews, P.L., Laven, R.D., 1996. Introduction to Wildland Fire. John Wiley \& Sons, New York, NY.

R Development Core Team, 2012. R: A Language and Environment for Statistical Computing. R Fondation for Statistical Computing, Vienna, Austria.
Satyam, V., Jayakumar, S., 2012. Impact of forest fire on physical, chemical and biological properties of soil: a review. In: Proceedings of the International Academy of Ecology and Environmental Sciences, vol. 2, pp. 168-176.

Savadogo, P., Tiveau, D., Sawadogo, L., Tigabu, M., 2008. Herbaceous species responses to long term effects of prescribe fire, grazing and selective cutting tree in the savanna-woodland of west Africa. Perspect. Plant Ecolog., Evol. Syst. 10, 179-195.

Savadogo, P., Zida, D., Sawadogo, L., Tiveau, D., Tigabu, M., Odén, P.C., 2007. Fuel and fire characteristics in savanna-woodland ofWest Africa in relation to grazing and dominant grass type. Int.J. Wildland Fire 16, 531-539.

Sawadogo, L., Tiveau, D., Nygård, R., 2005. Influence of selective tree cutting, livestock and prescribed fire on herbaceous biomass in the savannah woodlands of Burkina Faso, West Africa. Agric. Ecosyst. Environ. Int. 105 335-345.

Steward, F.R., Peter, S., Richon, J.B., 1990. A method for predicting the depth of letha heat penetration into mineral soils exposed to fires of various intensities. Can. J. For. Res. 20, 919-926.

Swaine, M.D., Hawthorne, W.D., Orgle, T.K., 1992. The effects of fire exclusion on savanna vegetation at Kpong, Ghana. Biotopica 24, 166-172.

Theresa, B.J., William, A.G., Russell, T., Graham, D.S., Pilliod, L.B.L., Gonzalez, G., 2008. A soil burn severity index for understanding soil-fire relations in tropical forests. Ambio 37 (7-8), 563-568.

Dawes-Gromadzki, T.Z., 2007. Short-term effects of low intensity fire on soil macroinvertebrate assemblages in different vegetation patch types in an Australian tropical savanna. Aust. Ecol. 32, 663-668.

Trollope, W.S.W., Trollope, L.A., Hartnett, D.C., 2002. Fire Behaviour A Key Factor in the Ecology of African Grasslands and Savannas. Millpress, Rotterdam.

Underwood, E.C., Christian, C.E., 2009. Consequences of Prescribed Fire and Grazing on Grassland Ant Communities. Environ. Entomol. 38, 325-332.

Uys, C., Hamer, M., 2007. The effect of long-term fire treatments on invertebrates: results from experimental plots at Cathedral Peak, South Africa. Afr. J. Range Forage Sci. 24, 1-7.

Vasconcelos, H.L., Pacheco, R., Silva, R.C., Vasconcelos, P.B., Lopes, C.T., Costa, A.N. Bruna, E.M., 2009. Dynamics of the leaf-litter arthropod fauna following fire in a neotropical woodland savanna. PLoS One 4 (11), e7762.

Wikars, L.O., Schimmel, J., 2001. Immediate effects of fire severity on soil invertebrates in cut and uncut pine forests. For. Ecol. Manage. 141, 189-200.

Zida, D., 2007. Impact of forest management regimes on lignous regeneration in the sudanian savanna of Burkina Faso. In: Ph.D. Thesis. No. 2007:66. Faculty of Forest Sciences, Swedish University of Agricultural Sciences, Uppsala, pp. 44. 